\title{
ANTIBACTERIAL ACTIVITY OF CHITOSAN AND HYDROLYZED COCONUT OIL AND THEIR COMBINATION AGAINST BACILLUS CEREUS AND ESCHERICHIA COLI
}

\author{
JANSEN SILALAHI ${ }^{1 *}$, PETRIKA SITUMORANG ${ }^{1}$, POPI PATILAYA ${ }^{1}$, YOSY CE SILALAHI ${ }^{2}$
}

${ }^{1}$ Faculty of Pharmacy, University of Sumatera Utara, Medan, 20155, Indonesia. ${ }^{2}$ Departement of Pharmacy, University of Sari Mutiara, Medan, Indonesia. Email: jansen@usu.ac.id

Received: 18 March 2016, Revised and Accepted: 24 March 2016

\section{ABSTRACT}

Objective: The purpose of this study was to evaluate the antibacterial activity of chitosan, hydrolyzed coconut oil and their combination against Bacillus cereus and Escherichia coli.

Methods: The materials used in this study were powder of chitosan (obtained from prawn shell produced by Laboratory of Research Centre FMIPA University of Sumatera Utara) and virgin coconut oil (VCO) product of Siti Nurbaya-Indonesia. VCO was partially hydrolyzed by Lipozyme TL ${ }^{\circledR}$ IM (active at $s n-1,3$ position) and the result called hydrolyzed virgin coconut oil (HVCO). The bacteria used in this study were B. cereus and E. coli. The antibacterial activity of chitosan in 1\% acetic acid and HVCO in dimethylsulfoxide was tested by Kirby-Bauer agar diffusion method using paper disc with diameter of $6 \mathrm{~mm}$.

Results: The results showed that the minimum inhibitory concentration of chitosan against B. cereus and E. coli is at concentration of $0.05 \%$ with inhibition zone diameter of $6.86 \mathrm{~mm}$ and $7.56 \mathrm{~mm}$, respectively. MIC of HVCO against B. cereus is at concentration of $0.25 \%$ with inhibition zone diameter of $6.40 \mathrm{~mm}$, and against $E$. coli is at a concentration of $0.50 \%$ with inhibition zone diameter of $6.20 \mathrm{~mm}$. The inhibition zone diameter of chitosan $0.05 \%$ and HVCO $0.25 \%$ in combination against B. cereus is $8.33 \mathrm{~mm}$ which is higher than half the sum of chitosan $0.05 \%$ and $\mathrm{HVCO} 0.25 \%$ $(6.63 \mathrm{~mm})$. The inhibition zone diameter of chitosan $0.05 \%$ and $0.5 \%$ HVCO in combination against $E$. coli is $8.53 \mathrm{~mm}$ which is higher than half the sum of chitosan $0.05 \%$ and HVCO $0.5 \%$ (6.53 mm).

Conclusion: The findings of this study indicate that chitosan is more antibacterial than HVCO, and the interaction between chitosan and HVCO in combination demonstrated to be synergistic against B. cereus and E. coli.

Keywords: Antibacterial, Chitosan, Coconut oil, Combination, Bacillus cereus, Escherichia coli.

(C) 2016 The Authors. Published by Innovare Academic Sciences Pvt Ltd. This is an open access article under the CC BY license (http://creativecommons. org/licenses/by/4. 0/) DOI: http://dx.doi.org/10.22159/ajpcr.2016.v9i5.11768

\section{INTRODUCTION}

Indiscriminate use of antibiotics may result in antibiotic resistance due to the evolutionary adaptation of bacteria, and the antibiotics resistance becomes a threat among medical community. Therefore, there is a need for continuous study to discover new antimicrobial compounds with novel mechanisms of activity to treat new infection. Therefore, more studies are turning to explore antimicrobial agents from plant origin. Essential plant oils were tested and revealed to be active against biofilm forming methicillin-resistant Staphylococcus aureus and mecA protein of methicillin-resistant $S$. aureus [1,2].

Coconut oil has been used in health promotion, diseases prevention, and medication $[3,4]$. Coconut oil composed of medium chain fatty acids, it is hydrolyzed by lingual and gastric lipase into free fatty acids and directly delivered into the liver through the portal vein and quickly oxidized to produce energy and increases metabolism and was demonstrated to enhance stamina [5]. Coconut oil was reported to be more effective in burn wound healing than Bioplacenton ${ }^{\circledR}$, a pharmaceutical dosage form used for the treatment of burns is in the form of gel containing bovine placenta extract and antibiotic neomycin and water [6]. Monolaurin and lauric acid are natural virucidal and bactericidal agent can be generated by partial hydrolysis of coconut oil $[7,8]$.

Triglyceride and diglyceride are not active as antibacterial, but fatty acids and monoglycerol esters (monoglyceride) are potential antibacterial agents. Antibacterial activity of fatty acids is influenced by chain length and unsaturation. Lauric acid (C12:0) is the most active among the saturated fatty acids against Gram-positive microorganism. Monoenoic acid (C18:1) is more active than long saturated fatty acid (C16:0), but less active than dienoic acid (C18:2). Of the monoglycerol esters, monoglycerol laurate (monolaurin) is the most active [7,9-11] Enzymatic hydrolysis was applied to partially hydrolyze coconut oil to produce lauric acid and monolaurin and demonstrated to be more effective toward pathogenic bacteria (Salmonella) than probiotic (Lactobacillus) [11]. Monolaurin and lauric acid are potent antimicrobial by damaging plasma membrane lipid, and antibacterial action is higher toward Gram-positive microorganism $[7,8]$.

Chitosan is polysaccharide composed of D-glucosamine as monomer linked with $\beta-(1,4)$ glycosidic bond. Although various theories have been proposed to explain the mechanism of the antibacterial activity of chitosan, intercellular leakage hypothesis is widely accepted. Positive charge of chitosan binds to the negative charge of the bacterial surface leading to altered membrane permeability resulting in leakage of intracellular constituents causing cell death. Therefore, the antibacterial activity of chitosan is limited to the acidic condition due to the loss of positive charge of the amino group at neutral $\mathrm{pH}$. The positive charge on the $\mathrm{C}-2$ of the glucosamine monomer below $\mathrm{pH}$ 6, chitosan is more soluble and has antimicrobial activity [12]. Antibacterial action of chitosan to the bacterial suspension seemed to have a stronger impact on the Gram-negative Escherichia coli than on the Gram-positive $S$. aureus in terms of the leakage of enzymes. It is also revealed that the antibacterial action of chitosan not only involves a reaction the cell wall of the bacteria, but that it may also affect the structure of the phospholipid bilayer in the cell membrane resulting in the release of some of the cellular components [13-16].

Bacillus cereus and E. coli are gastrointestinal pathogenic bacteria that may cause diarrhea. This infection is usually treated with antibiotic and body fluid normalization. However, the frequent and indiscriminate use 
of antibiotic may result in antibiotic resistance and hence the infection becomes more problematic [17-21]. The use of antibacterial agents in combination is a valuable alternative to delay or prevent antibiotic resistance [20,22]. Free fatty acids mainly lauric acid and monoglycerides dominated by monolaurin that can be derived from coconut oil virgin coconut oil (VCO) are active as antibacterial by destroying lipid-coated bacteria. Chitosan is also active by altering membrane permeability resulted in membrane leakage causing cell death $[7,8,12]$ Therefore, the combination of chitosan and hydrolyzed coconut oil is hypothesized to be synergistic. The aim of this study was to examine the antibacterial activity of hydrolyzed coconut oil and chitosan and their interaction against Gram-positive bacteria B. cereus and Gram-negative E. coli. Antibacterial test used was Kirby-Bauer diffusion agar method using the paper disc.

\section{METHODS}

Apparatus used in this study including analytical balance (sartorius) hot plate (Heidelberg, Germany), autoclave (Fisons), oven (Memmert), spectrophotometer (Shimadzu, Japan), incubator (Memmert), laminar air flow cabinet (Astec HLF I200 L), refrigerator (Toshiba), micro pipet, water bath, petri dish, paper disc with $6 \mathrm{~mm}$ in diameter (Oxoid), magnetic stirrer, separating funnel, burette, and glass wares.

All chemicals used were pro analysis grade product of E. Merck (Germany) including potassium and sodium hydroxide, n-hexane, methanol, ethanol, hydrochloride acid, calcium chloride, trishydroxymethylaminomethane (Tris- $\mathrm{HCl}$ ), anhydrous sodium sulfate, dimethylsulfoxide (DMSO) (Merck), acetic acid, phenolphthalein, and lypozyme TL IM. Tris-HCl buffer solution with the $\mathrm{pH}$ of 8 was prepared by dissolving $12.11 \mathrm{~g}$ Tris- $\mathrm{HCl}$ in $4.2 \mathrm{ml}$ concentrated $\mathrm{HCl}$ and the mixture was made to $100 \mathrm{ml}$ with distilled water. Solutions of $\mathrm{HCl}$ of $0.5 \mathrm{~N}, \mathrm{KOH}$ of $0.5 \mathrm{~N}$, calcium chloride of $0.063 \mathrm{M}$, and $1 \%$ phenolphthalein in alcohol, acetic solution were prepared according to the procedure described in Indonesian Pharmacopeia [23].

Materials used in this study were chitosan powder produced and obtained from Research Laboratory Faculty of Mathematics and Natural Sciences University of Sumatera Utara Medan Indonesia, coconut oil was the VCO product of Siti Nurbaya Indonesia. The medium used were Nutrient Broth (NB), and Mueller Hinton Agar (MHA) from Oxoid. Preparation of these media used as described in Difco Laboratory Manual [24]. Tested bacteria were B. cereus (ATCC 14579) and E. coli (ATCC 8939).

\section{Hydrolysis of VCO}

Hydrolysis procedure was carried out as described by Silalahi et al. [11]. $50 \mathrm{~g}$ of oil was placed in an Erlenmeyer of $250 \mathrm{ml}$, to which then $50 \mathrm{ml}$ of water, $12.5 \mathrm{ml} \mathrm{CaCl}_{2}$ of $0.063 \mathrm{M}, 25 \mathrm{ml}$ buffer tris- $\mathrm{HCl}$ solution with $\mathrm{pH}$ of 8 , and $500 \mathrm{mg}$ lipozyme TL IM were added. The mixture was stirred to homogenous, then incubated at $40^{\circ} \mathrm{C} \pm 0.5^{\circ} \mathrm{C}$ for $14 \mathrm{hrs}$, and was stirred for 10 minutes in every $1 \mathrm{hr}$ during incubation. The result was transferred into separating funnel, extracted with $50 \mathrm{ml} n$-hexane which resulted in two layers. The upper layer (n-hexane fraction) was separated (filtrate-1). The bottom layer was extracted again with $50 \mathrm{ml} \mathrm{n}$-hexane and separated to obtain filtrate-2. Both filtrates were combined and to which anhydrous $\mathrm{Na}_{2} \mathrm{SO}_{4}$ added and allowed to stand for 15 minutes. It was evaporated on water bath to dryness to obtain hydrolyzed virgin coconut oil (HVCO). The acid value was determined in by transferring $5 \mathrm{~g}$ sample into an Erlenmeyer of $200 \mathrm{ml}$. Added $25 \mathrm{ml}$ neutral alcohol of $95 \%$, then warmed for 10 minutes on water bath while stirred. Then, solution obtained was titrated with $\mathrm{KOH}$ of $0.1 \mathrm{~N}$ using phenolftalein of $1 \%$ in alcohol as an indicator. The end-point of titration was when the pink color appeared and then the acid value was calculated [11].

Acidvalue $=\frac{\mathrm{A} \times \mathrm{N} \times 56.1}{\mathrm{G}}$

$\mathrm{A}=$ Total volume of $\mathrm{ml} \mathrm{KOH}$ used for titration

$\mathrm{N}=$ Normality of $\mathrm{KOH}$ solution

$\mathrm{G}=$ Weight of hydrolyzed oil (gram).
Preparation of chitosan and HVCO solutions

Chitosan was dissolved in $1 \%$ acetic solution with concentration of $2.0 ; 1.5 ; 1.0 ; 0.18 ; 0.16 ; 0.14 ; 0.12 ; 0.10 ; 0.09 ; 0.08 ; 0.07 ; 0.06 ; 0.05$; $0.04 ; 0.03 ; 0.02$; and $0.01 \%(\mathrm{v} / \mathrm{v})$. HVCO was dissolved in DMSO with concentration of $100 ; 75 ; 50 ; 25 ; 10 ; 8 ; 6 ; 4 ; 2 ; 1 ; 0.75 ; 0.50 ; 0.25$ and $0.10 \%(\mathrm{v} / \mathrm{v})$.

\section{Inoculum preparation}

A colony of $B$. cereus and E. coli were taken by sterile loop, then planted on the slant agar media by scratching, then incubated in incubator at $32-35^{\circ} \mathrm{C}$ for $24 \mathrm{hrs}$. Inoculum was prepared by transferring bacteria from culture media, then planted in NB media, then incubated for 3-5 hrs, until the transmittance was $25 \%$ (total bacteria of $10^{6} \mathrm{cfu} / \mathrm{ml}$ ) measured at wavelength of $580 \mathrm{~nm}[11,23]$.

\section{Antibacterial activity test of chitosan and HVCO}

The amount of $0.1 \mathrm{ml}$ inoculum was placed in sterile petri dish, to which $15 \mathrm{ml}$ MHA was poured at $40-50^{\circ} \mathrm{C}$, then the petri dish was agitated on the table so the media and bacterial suspension mixed well and allowed to solidify. Paper disc was impregnated with the tested material for \pm 15 minutes. Impregnated paper disc was placed on solidified media, then allowed to stand for \pm 15 , then incubated at $35 \pm 2{ }^{\circ} \mathrm{C}$ for 18-24 hrs [11]. Antibacterial activity test also was conducted on solvent acetic acid solution (1\%). Similarly, a test also conducted on tetracycline as positive control and acetic acid solution and DMSO as negative control. Diameter of clear area around each paper disc was measured as inhibition zone for each tested material. The lowest concentration of tested solution that is still active to inhibit bacterial growth indicated by measurable clear area around the paper disc, and this concentration is called as minimum inhibitory concentration (MIC) [25].

\section{Antibacterial activity test of chitosan and HVCO in combination}

Antibacterial activity of containing chitosan and HVCO in combination was determined. Solutions containing chitosan at $0.05 \%$ (MIC of chitosan) and various concentration of HVCO were prepared. These solutions included (1) solution of $0.05 \%$ chitosan and $0.25 \%$ HVCO, (2) solution of $0.05 \%$ chitosan and $0.5 \%$ HVCO, (3) solution of $0.05 \%$ chitosan and $0.75 \%$ HVCO, (4) solution of $0.05 \%$ chitosan and $1.0 \%$ HVCO. Antibacterial test of these solutions was tested by procedure as described above. Antibacterial action of combination was quantitatively determined by the method described in previous studies [25].

$\mathrm{X}=\frac{\text { Inhibition zone of chitosan }+ \text { Inhibition zone of HVCO }}{2}$

$\mathrm{Y}=$ Inhibition zone of combination

$\mathrm{Y}-\mathrm{X}=+($ positive $)=$ Synergistic effect

The synergistic effect was also qualitatively evaluated by Kirby-Bauer diffusion agar method. Impregnated paper disc of chitosan and of HVCO were placed in the prepared media at a distance equal to the sum of the zone radii of inhibition of each tested materials when tested separately, then allowed to stand for \pm 15 minutes and then incubated at $35^{\circ} \mathrm{C} \pm 2^{\circ} \mathrm{C}$ for $18-24 \mathrm{hrs}$ and then the interface of zone was examined. Synergistic effect is indicated by bridging at junction of two zones of inhibition [26].

\section{RESULTS AND DISCUSSION}

\section{Degree of hydrolysis of coconut oil}

Acid value is a measure for total of free fatty acid contained in oil or fat which is defined as the number of milligrams of potassium hydroxyde required to neutralize the free fatty acids in $1 \mathrm{~g}$ of the sample. In this study, enzymatic hydrolysis was carried out on VCO. Acid value of hydrolyzed oil was determined after complete hydrolysis by lipase enzyme for $14 \mathrm{hrs}$ [8]. Acid values of the HVCO were $167.9 \mathrm{mg} \mathrm{KOH} / \mathrm{g}$, which is lower than saponification value $(\sim 250)$ in which all the fatty acids in triglycerides (in coconut oil) is saponified or hydrolyzed [27]. This is to indicate that only about 65\% (two-thirds) of the total fatty 
acids present in the oil because enzyme used in this experiment specifically active only $s n-1,3$ positions in triglyceride molecule. The hydrolyzed coconut oil composed or a mixture of free fatty acids and 2-monoglycrols mainly lauric acid and monolaurin mixture. This combination is potent antimicrobial agent [7].

\section{Antibacterial activity of chitosan}

Typical inhibition zone to evaluate the antibacterial activities of chitosan at various concentrations in $1 \%$ acetic acid against B. cereus and E. coli was carried out by measuring diameter of paper disc diameter in agar media and the results is presented in Fig. 1 and Table 1.

As can be seen in Table 1, MIC of chitosan against B. cereus and E. coli were $0.05 \%$ with diameter of inhibition zone were $6.86 \mathrm{~mm}$ and $7.56 \mathrm{~mm}$, respectively. These values are higher than inhibition zone diameter by the solvent used (acetic acid 1\%) against B. cereus and E. coli were 6.30 and $6.20 \mathrm{~mm}$. Antibacterial activity of chitosan at a concentration of $0.18-2.0 \%$ tend to decrease. This could be due to the chitosan molecule size because as the concentration increase in acetic acid $1 \%$, the solution become more viscous; hence, it is more difficult to diffuse in the agar medium $[13,28]$.

The range of MIC of chitosan was $0.05-0.1 \%$ depending on the type of bacteria and molecular weight of chitosan and different bacterial growth $[14,29]$. Chitosan is more active against Gram-negative bacteria E. coli than Gram-positive B. cereus, and the similar results were reported by previous studies $[15,16]$. Cell wall hydrophilicity and the distribution of negative charge on the cell surfaces may also affect the antibacterial activity of chitosan [30].

\section{Antibacterial activity of HVCO}

Antibacterial activities of HVCO is determined by measuring the diameter of the transparent area around the paper disc in agar media of different concentrations, and the typical inhibition zone is presented in Fig. 2 and results of measurements are shown in Table 2.

Table 1: Effect of chitosan on antibacterial activity against $B$, cereus and $E$, coli

\begin{tabular}{|c|c|c|}
\hline \multirow[t]{2}{*}{$\begin{array}{l}\text { Chitosan in } 1 \% \text { acetic } \\
\text { acid solution }(\%)\end{array}$} & \multicolumn{2}{|c|}{$\begin{array}{l}\text { Inhibition zone } \\
\text { diameter }(\mathrm{mm}) \pm S D ; n=3\end{array}$} \\
\hline & B. cereus & E. coli \\
\hline Blank (acetic acid 1\%) & 6.30 & 6.20 \\
\hline $\begin{array}{l}\text { Positive control } \\
\text { (tetracyclin } 30 \mu \mathrm{g} \text { ) }\end{array}$ & 12.70 & 12.60 \\
\hline 2.00 & $6.23 \pm 0.15$ & $6.26 \pm 0.12$ \\
\hline 1.50 & $6.26 \pm 0.21$ & $6.43 \pm 0.12$ \\
\hline 1.00 & $7.60 \pm 0.17$ & $7.80 \pm 0.26$ \\
\hline 0.80 & $7.93 \pm 0.15$ & $7.83 \pm 0.15$ \\
\hline 0.60 & $7.86 \pm 0.12$ & $8.06 \pm 0.12$ \\
\hline 0.40 & $7.93 \pm 0.12$ & $8.46 \pm 0.15$ \\
\hline 0.20 & $8.30 \pm 0.20$ & $8.93 \pm 0.06$ \\
\hline 0.18 & $8.43 \pm 0.12$ & $8.80 \pm 0.17$ \\
\hline 0.16 & $8.46 \pm 0.15$ & $8.63 \pm 0.21$ \\
\hline 0.14 & $8.33 \pm 0.15$ & $8.46 \pm 0.35$ \\
\hline 0.12 & $8.40 \pm 0.15$ & $8.33 \pm 0.15$ \\
\hline 0.10 & $8.23 \pm 0.25$ & $8.26 \pm 0.06$ \\
\hline 0.09 & $8.06 \pm 0.26$ & $8.26 \pm 0.25$ \\
\hline 0.08 & $7.80 \pm 0.10$ & $8.23 \pm 0.06$ \\
\hline 0.07 & $7.56 \pm 0.15$ & $8.16 \pm 0.15$ \\
\hline 0.06 & $7.33 \pm 0.15$ & $7.96 \pm 0.15$ \\
\hline$* 0.05$ & $6.86 \pm 0.12$ & $7.56 \pm 0.31$ \\
\hline 0.04 & $6.10 \pm 0.21$ & $6.13 \pm 0.07$ \\
\hline 0.03 & - & - \\
\hline 0.02 & - & - \\
\hline 0.01 & - & - \\
\hline
\end{tabular}

Data are the average of three replicates; -: Diameter of paper disc $(6 \mathrm{~mm})$. *Minimum inhibitory concentration of chitosan against tested bacteria. B. cereus: Bacillus cereus, E. coli: Escherichia coli
MIC of HVCO on tested bacteria was different. HVCO was more active toward B. cereus shown by MIC of $0.25 \%$ with diameter of $6.40 \mathrm{~mm}$, whereas MIC of HVCO was $0.50 \%$ on E. coli with diameter of $6.20 \mathrm{~mm}$. This result is comparable with results reported by previous researchers $[8,10,19]$.

Antimicrobial action of HVCO was due to the free fatty acids and monoglycerides in the hydrolyzed VCO mainly lauric acid and monolaurin as results of partial hydrolysis of VCO by an enzyme that is active on $s n-1,3$ position in TAGs molecules [11].

\section{Antibacterial activity of chitosan and HVCO in combination}

The antibacterial action of chitosan and HVCO in combination was conducted on solutions containing chitosan of $0.05 \%$ and different concentrations of HVCO, and the result is presented in Fig. 3. The effect of the combination was evaluated by measuring of inhibition zone diameter and then compared with the sum of inhibition zone of each tested material divided by 2 as presented in Tables 3 and 4 .

Antibacterial activity of chitosan and HVCO in combination was demonstrated to be synergistic indicated by positive values. As can be seen from Table 3, synergistic effect was increased with increasing concentration of HVCO in each combination against B. cereus. A similar trend was also demonstrated in the synergistic effect of chitosan and HVCO combination against $E$. coli as shown in Table 4. This was consistently shown by the higher inhibition zone caused by tested

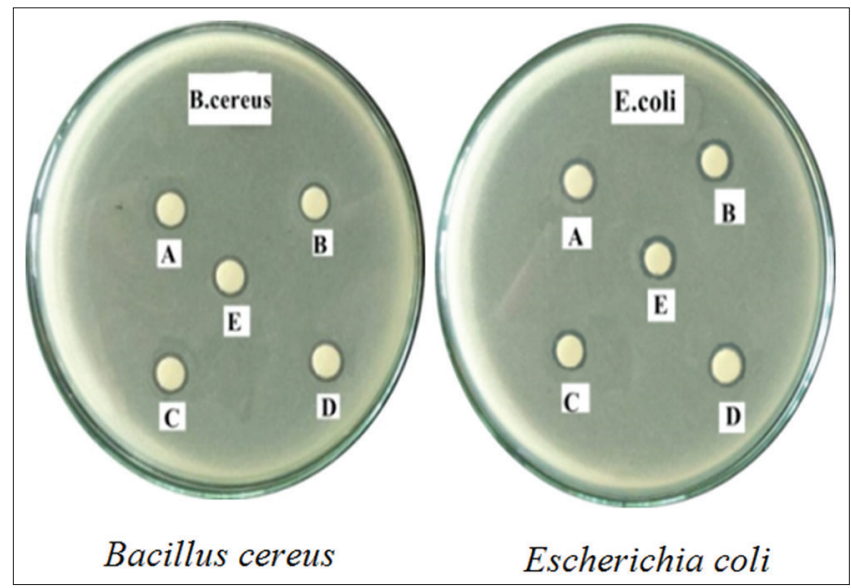

Fig. 1: Inhibition zone diameter of chitosan $0.12 \%$ (A); chitosan $0.14 \%$ (B); chitosan $0.16 \%$ (C); chitosan $0.18 \%$ (D); chitosan $0.2 \%$ (E)

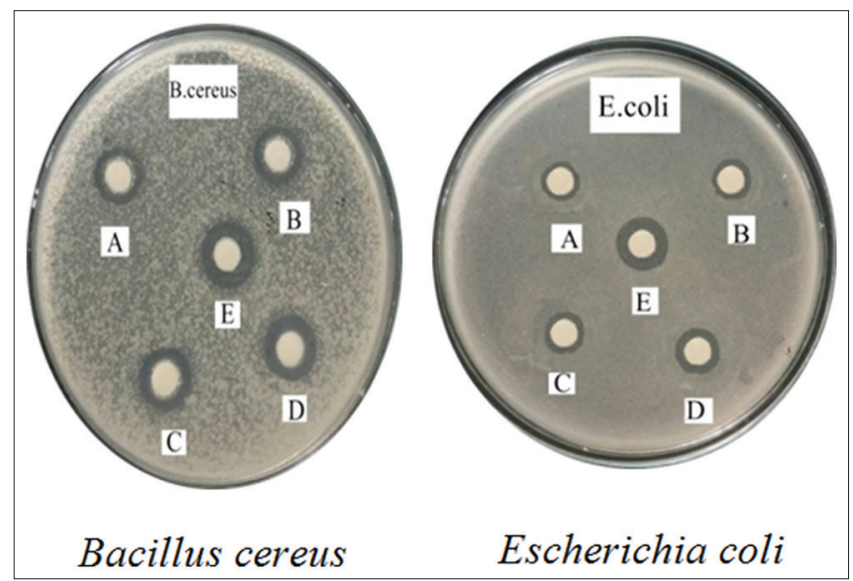

Fig. 2: Inhibition zone diameter of hydrolyzed virgin coconut oi (HVCO) 10\% (A); HVCO 25\% (B); HVCO 50\% (C); HVCO 75\% (D); and HVCO $100 \%$ (E) toward tested bacteria 
materials in combination compared to the sum of inhibition zone of chitosan plus inhibition zone of HVCO divided by 2 for every combination.

For example, from Table 3, inhibition zone diameter of solution containing HVCO $0.25 \%$ and chitosan $0.05 \%$ in combination against B. cereus was $8.33 \mathrm{~mm}$ higher than the sum of half inhibition zone diameter of chitosan $0.05 \%$ plus that of HVCO $0.25 \%$ that was $6.63 \mathrm{~mm}$. The degree of synergistic effect of the combination was quantitatively determined by the nominal value, that is the difference of inhibition zone of combination and the sum of inhibition zone of single agent divided by 2 , and this difference is $8.33-6.63=1.70 \mathrm{~mm}$.

Antimicrobial agent interaction between chitosan and HVCO in combination was also qualitatively evaluated by Kirby-Bauer diffusion method [25], and the results presented in Fig. 4.

Table 2: Effect of HVCO concentration on growth inhibition of

$$
\text { B. cereus and } E \text {. coli }
$$

\begin{tabular}{lll}
\hline HVCO concentration (\%) & \multicolumn{2}{l}{$\begin{array}{l}\text { Inhibition zone } \\
\text { diameter }(\mathbf{m m})\end{array}$} \\
\cline { 2 - 3 } & (n=3) \\
\cline { 2 - 3 } & B. cereus & E. coli \\
\hline Blank (DMSO) & - & - \\
Positive control (tetracyclin $30 \mu \mathrm{g})$ & 12.70 & 12.60 \\
100 & $14.33 \pm 0.25$ & $13.40 \pm 0.10$ \\
75 & $13.56 \pm 0.12$ & $12.73 \pm 0.21$ \\
50 & $12.96 \pm 0.21$ & $11.53 \pm 0.15$ \\
25 & $11.73 \pm 0.15$ & $10.13 \pm 0.10$ \\
10 & $10.90 \pm 0.10$ & $9.60 \pm 0.10$ \\
8 & $10.40 \pm 0.20$ & $9.13 \pm 0.15$ \\
6 & $9.76 \pm 0.15$ & $8.33 \pm 0.15$ \\
4 & $9.33 \pm 0.15$ & $8.06 \pm 0.12$ \\
2 & $8.63 \pm 0.15$ & $7.40 \pm 0.10$ \\
1 & $8.10 \pm 0.17$ & $6.90 \pm 0.10$ \\
0.75 & $7.46 \pm 0.15$ & $6.63 \pm 0.06$ \\
$* 0.50$ & $6.86 \pm 0.15$ & $6.20 \pm 0.10$ \\
$* * 0.25$ & $6.40 \pm 0.06$ & - \\
0.1 & - & - \\
\hline
\end{tabular}

Data are the average of three replicates; -: Diameter of paper disc $(6 \mathrm{~mm})$. ${ }^{*}$ MIC of HVCO against E. coli. **MIC of HVCO against B. cereus. MIC: Minimum inhibitory concentration, B. cereus: Bacillus cereus, E. coli: Escherichia coli, HVCO: Hydrolyzed virgin coconut oil, DMSO: Dimethylsulfoxide
Synergistic effect was shown by the formation of a bridge connecting the inhibition zone area between inhibition zones of the paper disc

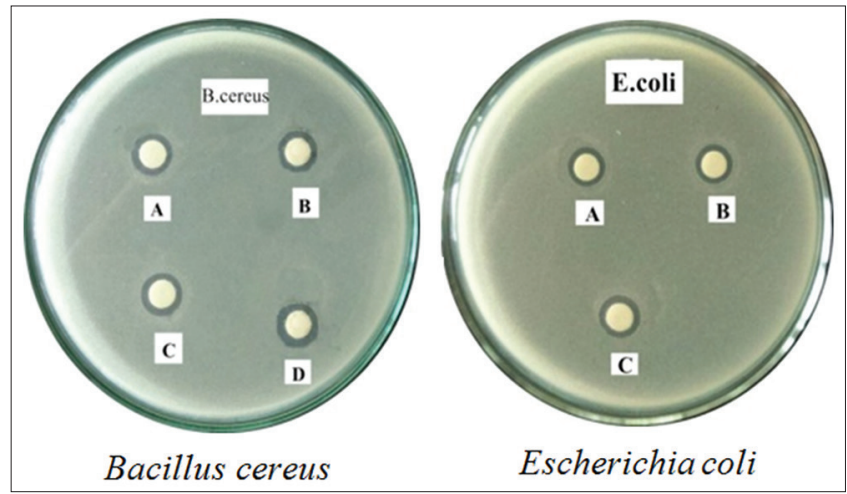

Fig. 3: Zone inhibition diameter of chitosan and hydrolyzed virgin coconut oil (HVCO) in combination; chitosan $0.05 \%$ and HVCO 1.0\% (A); chitosan $0.05 \%$ and HVCO $0.75 \%$ (B); chitosan $0.05 \%$ and HVCO $0.50 \%$ (C); chitosan $0.05 \%$ and HVCO $0.25 \%$ (D)
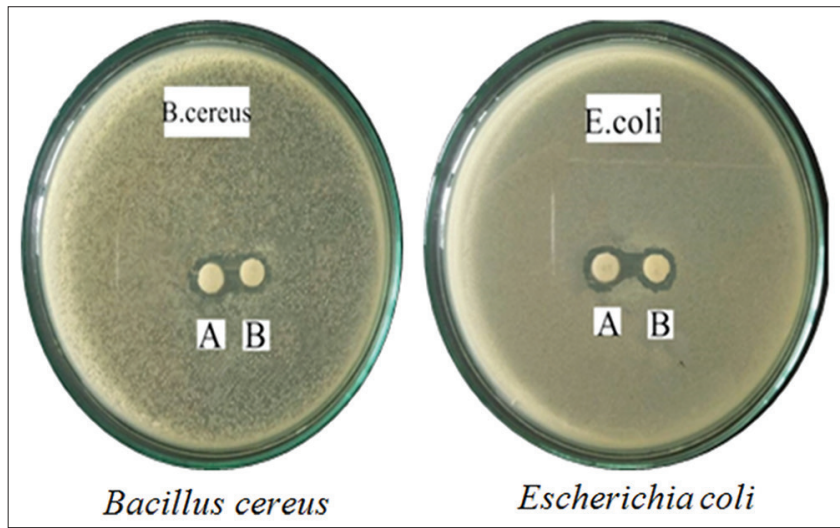

Fig. 4: Synergistic effect of hydrolyzed virgin coconut oil $1 \%$ (A) and chitosan $0.05 \%$ (B) in combination indicated by the formation of a bridge between inhibition zones

Table 3: Interaction effect of chitosan and HVCO combination on Bacillus cereus

\begin{tabular}{|c|c|c|c|c|c|c|c|}
\hline \multicolumn{2}{|c|}{ Chitosan in acetic acid $1 \%$} & \multicolumn{2}{|l|}{ HVCO in DMSO } & \multirow{2}{*}{$\begin{array}{l}\frac{\mathrm{A}+\mathrm{B}}{2} \\
\begin{array}{l}\text { Inhibition zone } \\
(\mathrm{mm})(\mathrm{X})\end{array}\end{array}$} & \multirow{2}{*}{$\begin{array}{l}\text { Combination } \\
\begin{array}{l}\text { Inhibition zone } \\
(\mathrm{mm})(\mathrm{Y}) \pm \mathrm{SD}\end{array} \\
\end{array}$} & \multirow{2}{*}{$\begin{array}{l}Y-X \\
(\mathrm{~mm})\end{array}$} & \multirow[t]{2}{*}{ Interaction } \\
\hline $\begin{array}{l}\text { Concentration } \\
(\%)\end{array}$ & $\begin{array}{l}\text { Inhibition zone } \\
(\mathrm{mm}) \pm S D(A)\end{array}$ & $\begin{array}{l}\text { Concentration } \\
(\%)\end{array}$ & $\begin{array}{l}\text { Inhibition zone } \\
(\mathrm{mm}) \pm S D(B)\end{array}$ & & & & \\
\hline 0.05 & $6.86 \pm 0.15$ & 1.0 & $8.10 \pm 0.17$ & 7.48 & $10.13 \pm 0.21$ & 2.65 & + \\
\hline 0.05 & $6.86 \pm 0.15$ & 0.75 & $7.46 \pm 0.15$ & 7.16 & $9.43 \pm 0.15$ & 2.27 & + \\
\hline 0.05 & $6.86 \pm 0.15$ & 0.50 & $6.86 \pm 0.15$ & 6.86 & $8.70 \pm 0.10$ & 1.84 & + \\
\hline 0.05 & $6.86 \pm 0.15$ & 0.25 & $6.40 \pm 0.06$ & 6.63 & $8.33 \pm 0.15$ & 1.70 & + \\
\hline
\end{tabular}

+: Synergistic; Data are the average of 3 replicates. HVCO: Hydrolyzed virgin coconut oil, DMSO: Dimethylsulfoxide

Table 4: Interaction effect of chitosan and HVCO combination on Escherichia coli

\begin{tabular}{|c|c|c|c|c|c|c|c|}
\hline \multicolumn{2}{|c|}{ Chitosan in acetic acid 1\% } & \multicolumn{2}{|l|}{ HVCO in DMSO } & \multirow{2}{*}{$\begin{array}{l}\frac{\mathrm{A}+\mathrm{B}}{2} \\
\begin{array}{l}\text { Inhibition zone } \\
(\mathrm{mm})(\mathrm{X})\end{array}\end{array}$} & \multirow{2}{*}{$\begin{array}{l}\text { Combination } \\
\begin{array}{l}\text { Inhibition zone } \\
(\mathrm{mm}) \pm S D(Y)\end{array}\end{array}$} & \multirow{2}{*}{$\begin{array}{l}\text { Y-X } \\
(\mathrm{mm})\end{array}$} & \multirow[t]{2}{*}{ Interaction } \\
\hline $\begin{array}{l}\text { Concentration } \\
(\%)\end{array}$ & $\begin{array}{l}\text { Inhibition zone } \\
(\mathrm{mm}) \pm S D(A)\end{array}$ & $\begin{array}{l}\text { Concentration } \\
(\%)\end{array}$ & $\begin{array}{l}\text { Inhibition zone } \\
(\mathrm{mm}) \pm S D(B)\end{array}$ & & & & \\
\hline 0.05 & $6.86 \pm 0.15$ & 1.0 & $6.90 \pm 0.10$ & 6.88 & $9.63 \pm 0.15$ & 2.75 & + \\
\hline 0.05 & $6.86 \pm 0.15$ & 0.75 & $6.63 \pm 0.06$ & 6.75 & $9.13 \pm 0.12$ & 2.38 & + \\
\hline 0.05 & $6.86 \pm 0.15$ & 0.50 & $6.20 \pm 0.10$ & 6.53 & $8.53 \pm 0.15$ & 2.00 & + \\
\hline
\end{tabular}

+: Synergistic; data are the average of 3 replicates. HVCO: Hydrolyzed virgin coconut oil, DMSO: Dimethylsulfoxide, SD: Standard deviation 
containing HVCO $1 \%$ (A) and chitosan $0.05 \%$ (B) when planted in the distance of the sum of inhibition zone of each tested material as shown in Fig. 4. This was due to the combined effects of both antimicrobial agents. When the chitosan and HVCO diffused within the media and then their combination or mixture becomes more active [25].

\section{CONCLUSION}

Antibacterial activity of chitosan is more active (MIC of $0.05 \%$ ) than HVCO (MIC of $0.25 \%$ ) against tested bacteria. HVCO is more active (MIC of $0.25 \%$ ) toward B. cereus than (MIC of $0.50 \%$ ) against E. coli. The present results indicate that antibacterial activity of chitosan and HVCO combination demonstrated to be synergistic against $B$. cereus and E. coli.

\section{REFERENCES}

1. Punitha T, Moorthy K, Vijayalaksmhi P, Vinodhini R, Saranya S, Bhuvaneshwari $\mathrm{M}$, et al. In vitro antibacterial activity of essential plant oils against biofilm forming methicillin resistant Staphylococcus aureus. Asian J Pharm Clin Res 2014;7 Suppl 1:220-5.

2. Kaushik S, Tomar RS, Shrivastava V, Shrivastav A, Jain SK. Antimicrobial efficacy of essential oils of selected plants and vaccine design against meac protein of methicillin resistant Staphylococcus aureus. Asian J Pharm Clin Res 2014;7 Suppl 1:52-6.

3. Enig MG. Health and Nutritional Benefits from Coconut oil: An Important Functional Foods for the $21^{\text {st }}$ Century. AVOC Lauric Oil Symposium. Vietnam: Ho Chi Min City 25 April; 1996.

4. Enig MG. Health and nutritional benefits from coconut oil and its advantages over competing oils. Indian Coconut J 2010;53(5):9-15.

5. Silalahi J, Pertiwi D, Dalimunthe A, Silalahi YC. Effect of acute consumption of coconut and palm oil on swimming capacity endurance of mice (Mus musculus). Int J PharmTech Res 2015;8(9):55-9.

6. Silalahi J, Surbakti C. Burn wound healing activity of hydrolyzed virgin coconut oil. Int J PharmTech Res 2015;8(1):67-73.

7. Lieberman S, Enig MG, Preuss HG. A review of monolaurin and lauric acid. Natural virucidal and bactericidal agents. Alternat Complement Ther 2006;12(6):310-4

8. Silalahi J, Permata Y, Putra, Dan ED. Antibacterial activity of hydrolyzed virgin coconut oil. Asian J Pharm Clin Res 2014;7(2):90-4.

9. Kabara JJ, Swieczkowski DM, Conley AJ, Truant JP. Fatty acids and derivatives as antimicrobial agents. Antimicrob Agents Chemother 1972;2(1):23-8

10. Loung FS, Silalahi J, Suryanto D. Antibacterial activity of enzymatic hydrolyzed of virgin coconut oil and palm kernel oil against Staphylococcus aureus, Salmonella thypi and Escherichia coli. Int J PharmTech Res 2014;6(2):628-33.

11. Silalahi J, Manurung R, Sitompul, E. Antibacterial activity of hydrolyzed oil of different fatty acid composition against Salmonella tiphy and Lactobacillus plantarum. Int J PharmTech Res 2015;7(2):233-7.

12. Jeon SJ, Oh M, Yeo WS, Galvão KN, Jeong KC. Underlying mechanism of antimicrobial activity of chitosan microparticles and implications for the treatment of infectious diseases. PLoS One 2014;9(3):e92723.

13. Dutta J, Dutta PK. Antimicrobial activity of chitin, chitosan and their oligosaccharides. In: Kim SK, editor. Chitin, Chitosan, Oligosaccharides and Their Derivatives: Biological Activities and Aplications. New York: CRC Press; 2011. p. 195-209.

14. Eldin MS, Soliman EA, Hashem AI, Tamer TM. Antibacterial activity of chitosan chemically modified with new technique. Trends Biomater Artif Organ 2008;22(3):125-37.

15. Nurainy F, Rizal S, dan Yudiantoro. The effect of chitosan concentration on antibacterial activity by agar diffusion method (well). J Ind Technol Agric Prod 2008;13(2):117-25.

16. Yusman DA. Relationship between Antibacterial Activity of Chitosan and Surface Characteristics of Bacterial Cell Wall. Thesis, Departement of Chemistry, Faculty of Mathematics and Natural Sciences. Institut Pertanian Bogor; 2006.

17. Farthing M, Salam M. Acute Diarrhea in Adults and Children: A Global Perspective. World Gastroenterology Organization Global Guidelines; 2012

18. Hawley LB. Intisari Mikrobiologi \& Penyakit Infeksi. Jakarta: Hipokrates; 2003

19. Sihombing NT, Silalahi J, dan Suryanto D. Antibacterial activity of aqueous garlic (Allium sativum) extracts and virgin coconut oil and their combination against Bacillus cereus ATCC 14579 and Escherichia coli ATCC 8939 Int J ChemTech Res 2014;6(5):2774-82.

20. Adwan G, Shanab BA, Adwan K. Antibacterial activities of some plant extracts alone and in combination with different antimicrobials against multidrug-resistant Pseudomonas aureginosa strains. Asian Pac J Trop Med 2010;1:266-9.

21. Microbiology Team. Medical Bacteriolohy. Malang. Bayumedia Publishing; 2006

22. Setiabudy. Introduction in antimicrobial. In: Pharmacology and Therapheutics. Faculty of Medicine. $\mathrm{V}^{\text {th }}$ ed. Jakarta: University of Indonesia; 2007. p. 585

23. Difco Laboratories. Difco Manual of Dehydrated Media and Reagents for Microbiology and Clinical Laboratory Procedures. $9^{\text {th }}$ ed., Vol. 32. Detroit Michigan: Difco Laboratories; 1977. p. 64.

24. Directorate General POM. Indonesian Phrmacopeia. VI $I^{\text {th }}$ ed. Jakarta: Health Department of Republic of Indonesia; 1995. p. 896-8.

25. Pratiwi ST. Mikrobiologi Farmasi. Jakarta: Penerbit Erlangga; 2008.

26. Schwalbe R, Moore LS, Goodwin AC. Antimicrobial Susceptibility Testing Protocols. New York, USA: CRC Press; 2007.

27. O'Brien RD. Fats and Oils. Formulating and Processing for Applications. Boca Rotan: CRC Press; 2009. p. 414-5.

28. Kurniasih M, dan Karika D. Antibacterial activity of chitosan against $S$. aureus. Molekul 2009;4(1):1-5.

29. Liu N, Chen XG, Park HJ, Liu CG, Chen SL, Meng XH, et al. Effect of MW and concentration of chitosan antibacterial activity of Escherichic coli. Carbohydr Polym 2006;64:60-5.

30. Chung YC, Su YP, Chen CC, Jia G, Wang HL, Wu JC, et al. Relationship between antibacterial activity of chitosan and surface characteristics of cell wall. Acta Pharmacol Sin 2004;25(7):932-6. 